\title{
リスク概念に基づく建築物の設計可燃物密度 DESIGN FIRE LOAD DENSITY BASED ON RISK CONCEPT
}

\author{
大宮喜文*, 田中哮義**, 野竹宏彰*** \\ Yoshifumi OHMIYA, Takeyoshi TANAKA and Hiroaki NOTAKE
}

\begin{abstract}
It is quite common in fire safety codes of buildings that the higher or the larger the building, and the larger the number of occupants, the more strict the provisions applied. This, of course, intends to reduce the probability and the potential size of fire loss. Although the consistency of the principle and the attainable level of the prescriptive provisions of the existing codes is questionable, the favorable interpretation of their intention will be expressed in a scientific term as "to control fire risk under a certain level", that is, letting $R$ be the fire risk, $P_{L}$ be the probability of fire loss occurrence, $S_{L}$ be the potential size of the loss, and $R_{a}$ be the acceptable fire risk,

$$
R=P_{L} S_{L} \leq R_{a}
$$

By so considering, many provisions can be interpreted in a rational manner. For example, the fire resistance requirements on principal structural members intends to control the fire risk by lowering $P_{L}$; compartmentation and shaft sealing by limiting $S_{L}$ as well as to lowering $P_{L}$; provisions for safe escape routes are not imposed, or at least very lightly if any, for small buildings such as family dwellings because the potential size of life is so small. Under above concept, calculation method'of design fire load density was developed and case-study by proposed method was carried out in this paper.
\end{abstract}

Keywords: Fire load density, Fire resistance requirement, Fire risk, Failure probability, Probability distribution 可燃物密度, 要求耐火時間, 火災リスク, 崩壊確率, 確率分布

\section{1.はじめに}

これまで建築基淮法の防火関係規定は，一定規模以上の建築物の 構造部材に仕様的なかたちで規模や高さに応じた耐火性能を要求し てきた。例えば，主要構造部の柱に対しては，建築物の最上階から 4 層までは 1 時間, 5 層から 14 㸴までは 2 時間, 15 層以上では 3 時間の耐火時間が要求されている。一般には大規模な建築物ほど火 災により倒壊した場合の影響が大きいのであるから火災損害リスク の観点からみれば，このように層数の増加に従い耐火時間が厳しく なるのは合理的と言える。しかし，要求される耐火時間の与え方は 層数に対応して 1 時間刻みで定められているため, 1 階首分の違い により突如 1 時間の耐火時間のギャップが生じる階があるなど, 建 築物の設計上, 解消が望まれる課題がある。一方, 性能的而火設計 では設計火災に基づいて個々の建築物条件下での火災性状を評価し

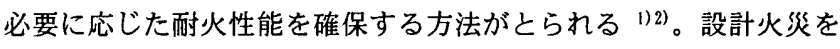
決定する最も重要な要素の一つである可燃物条件は，これまでに行 われた可燃物密度の実態調査研究などを基に設定されている ${ }^{3)}$ 。し かし, 可燃物密度の考え方にリスクの概念は存在せず, 各用途ごと に一律に与えられることが一般的であった。

そこで本稿では, 建築物の許容火災リスクは建築物の規模や階数 によらず一定であるべきという前提に立脚し，建築物の許容火災り スクの計算手法を提案し, 建築物の諸条件に応じた建築物の火災り

\section{スクを許容值以下に抑えるための設計可燃物密度の設定方法を検捨 する。}

\section{2. 建築物の許容火災リスクの考え方 \\ 2. 1 建築物の設計火災}

現在, 建築物の性能的耐火設計に用いる設計火災は, 図 1 に示さ れるような発熱速度の時間的経過を経る火災を想定している。すな わち, 火災初期には発熱速度が火災経過時間の 2 乗に比例して成長 し, その後, 換気あるいは可燃物の条件により制約される上限值に 達して一定になり, 可燃物が燃え尽きるまで発熱速度が維持される という想定である。

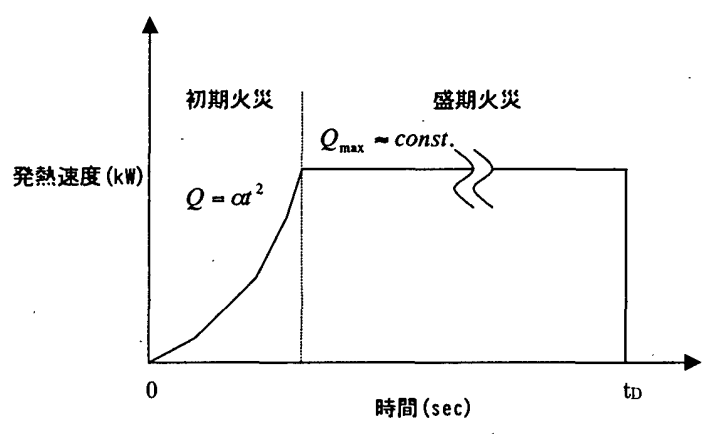

図1 設計火災の与え方
$*$ 独立行政法人建築研究所防火研究グループ 主任研究員.工博

** 京都大学防災研究所 教授・工博

*** 清水建設(姝和泉研究室 研究員
Chief Researcher, Building Research Institute, Dr. Eng.

Prof., DPRI, Kyoto University, Dr. Eng. Researcher, Izumi Research Institute, Shimizu Corp. 
建築物内の在館者の避難安全性を評価する場合には, $\mathrm{t}^{2}$ 火源 $(\mathrm{Q}=$ $\left.\alpha \mathrm{t}^{2}\right)$ で示される火災初期の発熱速度が重要である。一方, 建築物 の耐火時間など構造安定性を評価する場合には, 発熱速度の上限値 が継続する時間が重要であり，この時間が長いほど，構造部材に要 求される耐火性能も高くなる。この火災が継続する時間は火災区画 内に持ち込まれる可然物の潜在的発熱量の総量を発熱速度で除して 求められるので, 可燃物密度の設定值が直接的に要求耐火時間に影 響することになる。

\section{1）可燃物密度分布}

当然のことながら，建築物の室内に持ち込まれる可然物の密度は， 室の使用方法によって，また経年的にも変化し，一般には確率的分 布を示すことになる。図 2 は, 事務所用途の室の可燃物密度分布の 例を示したものである。図 2 の例のように建築物内に持ち込まれる 可燃物密度 $w\left(\mathrm{~kg} / \mathrm{m}^{2}\right)$ は対数正規分布に従う傾向を持つ ${ }^{3)}$ 。すなわち $\ln w$ が正規分布に従うことになるので，確率密度関数は，

$\Psi(\ln w)=\frac{1}{\sqrt{2 \pi} \sigma_{\ln w}} \exp \left\{-\frac{\left(\ln w-\mu_{\ln w}\right)^{2}}{2 \sigma_{\ln w}^{2}}\right\}$

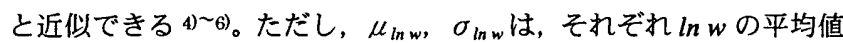
および標準偏差である。これらは， $\mu_{w} ， \sigma_{w}$ をそれぞれ可然物密度 の平均值および標準偏差とすれば,

$$
\begin{gathered}
\mu_{\ln w}=\ln \frac{\mu_{w}}{\sqrt{1+\left(\frac{\sigma_{w}}{\mu_{w}}\right)^{2}}} \\
\sigma_{\ln w}=\sqrt{\ln \left\{1+\left(\frac{\sigma_{w}}{\mu_{w}}\right)^{2}\right\}}
\end{gathered}
$$

となる。

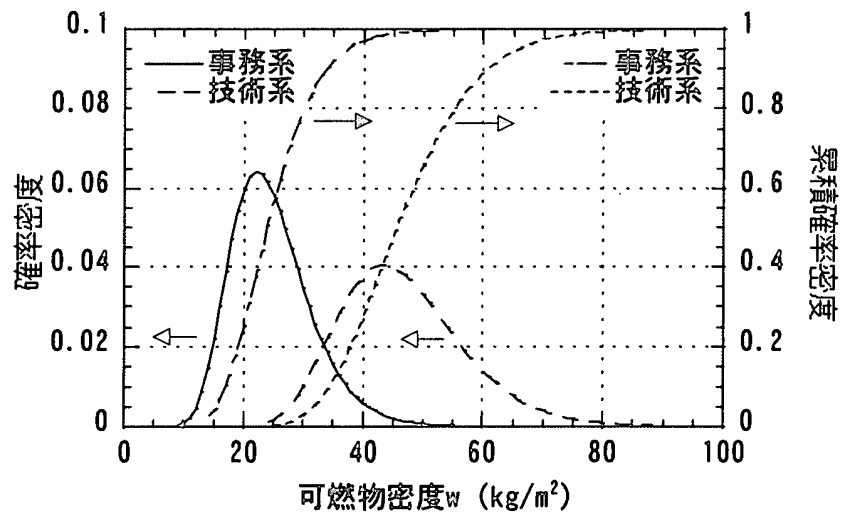

図2 烹務所の可然物密度分席 ${ }^{3)}$

\section{2 ）火災継続時間分布}

耐火設計で問題となる盛期の火炎継続時間 $\mathrm{t}(\mathrm{sec})$ は，区画内に持 ち込まれる可然物総量と可燃物の燃焼による重量减少速度（燃焼速 度）から次のように計算できる。

$t=\frac{W}{m_{b}}=\frac{A_{F L R} w}{m_{b}}$
ここに, $W, m_{b}, A_{F L R}$ はそれぞれ総可燃物量 $(\mathrm{kg})$, 燃焼速度 $(\mathrm{kg} / \mathrm{s})$, 空間床面積 $\left(\mathrm{m}^{2}\right)$ である。さらに,

$S \square \frac{A_{F L R}}{m_{b}} \approx \frac{A_{F L R}}{0.1 A \sqrt{H}}$

とおくと，

$t=S \cdot w$

であるから

$\ln t=\ln (S \cdot w)=\ln S+\ln w$

となる。よって，火災継続時間は，可燃物と同様の確率分布型を示 し, $\ln w$ が式(1)の正規分布 $\left[\mu_{l n w}, \sigma_{l n w}\right]$ に従うとき, $\ln t$ は式(1)の 分布を $\ln S$ だけ右に平行移動した正規分布 $\left[\mu_{l n w}+\ln S, \sigma_{l n w}\right]$ に従う こととなる。従って，火災継続時間の平均および標準偏差をそれぞ れ $\mu_{l n t}$ および $\sigma_{l n t}$ とすれば確率密度関数は,

$\Psi(\ln t)=\frac{1}{\sqrt{2 \pi} \sigma_{\ln t}} \exp \left\{-\frac{\left(\ln t-\mu_{\ln t}\right)^{2}}{2 \sigma_{\ln t}^{2}}\right\}$

となる。ここで $\mu_{l n t}$ および $\sigma_{l n t}$ は

$\mu_{\ln t}=\mu_{\ln w}+\ln S=\ln \frac{\mu_{w}}{\sqrt{1+\left(\frac{\sigma_{w}}{\mu_{w}}\right)^{2}}}+\ln S=\ln \frac{\mu_{w} S}{\sqrt{1+\left(\frac{\sigma_{w}}{\mu_{w}}\right)^{2}}}$

(9)

$\sigma_{\ln t}=\sigma_{\ln w}=\sqrt{\ln \left\{1+\left(\frac{\sigma_{w}}{\mu_{w}}\right)^{2}\right\}}$

と表せる。更に,

$\tau \square \frac{\ln t-\mu_{\ln t}}{\sigma_{\ln t}}$

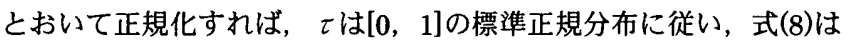

$\phi(\tau)=\frac{1}{\sqrt{2 \pi}} \exp \left(-\frac{\tau^{2}}{2}\right)$

と変換できる。

\section{2 堅築物の許容火災リスク}

日本に限らず，各国の建築法規は建築物の高さや規模が大きいほ ぞ高い酎火性能を要求している。これは極めて経験的な形であるに しろ, 建築物が火災で倒壊した場合の潜在的損害が考慮に入れられ， 潜在的損害が大きい建築物ほど倒壊のリスクを低減することが意図 されるものと考えられる。戸建住宅などで耐火性がそれ程求められ ていないのは, 火災が発生した場合の倒壊リスクが高い場合でも, 倒壊による潜在的損害が小さいためと考えられる。ここでは火災リ スクを火災によって建物構造が崩壊することによる損害の期待値と 定義し，火災リスクは建築物の高さや規模などに依らず一定の許容 火災リスク $\mathrm{R}_{\mathrm{a}}$ 以下でなくてはならないものと仮定する。すなわち， $R=P_{L} S_{L} \leq R_{a}$

ここでR：火災リスク， $\mathrm{P}_{\mathrm{L}}$ ：火災損害発生確率， $\mathrm{S}_{\mathrm{L}}$ ：火災損害の潜 在的大きさである。

さて,火災で建物構造が崩罗することによる損害が発生するのは, 火災が発生し成長して盛期火災になり，消防による鎮火が失敗し構 
造が火熱に耐えられなくて崩壊するという事象が連鎖した場合であ る。従って火炎損害の発生確率 $\mathrm{P}_{\mathrm{L}}(-)$ は

$P_{L}=\delta P_{\text {Fire }} P_{F O} P_{S U P} p_{\text {fail }}$

となる。ここに $\delta$ は安全率によるリスク低減係数 (-), $\mathrm{P}_{\mathrm{F} 0}$ は出火し た火災が火盛り期に成長する確率(-)， $\mathrm{P}_{\mathrm{SuP}}$ は消防が火災鎮圧に失敗 する確率 $(-), \mathrm{p}_{\mathrm{fa} \mid \mathrm{i}}$ は崩壊確率(-).である。火炎発生確率 $\mathrm{P}_{\mathrm{Fire}}(-)$ は, 空間規模と使用期間に比例すると考えるのが自然であるから

$P_{\text {Fire }}=P_{F} A_{F L R} Y_{L}$

とおける。ここで， $\mathrm{P}_{\mathrm{F}}$ は単位床面積当たり単位期間当たりの火災発 生確率 ( $1 / \mathrm{m}^{2}$ 年)， $\mathrm{A}_{\mathrm{FL} R}$ は階床面積 $\left(\mathrm{m}^{2}\right) ， \mathrm{Y}_{\mathrm{L}}$ は耐用年数 (年) とする。

ここで, 図 3 に示すように, 各階每に同じ床面積 $\mathrm{A}_{\mathrm{FLR}}$ を持つ多首 の建築物を想定し，火災が発生した階で主要な構造部が崩壊した場 合，その火災階より上方の階についても使用が不可能となると考え ると, 潜在的火災損害 $\mathrm{S}_{\mathrm{L}}$ は,

$S_{L}=N A_{F L R} I$

である。ただし，N は火災階より上方の建物階数 (階)，I は建築物重 要度 $(-)$ である。

N陼

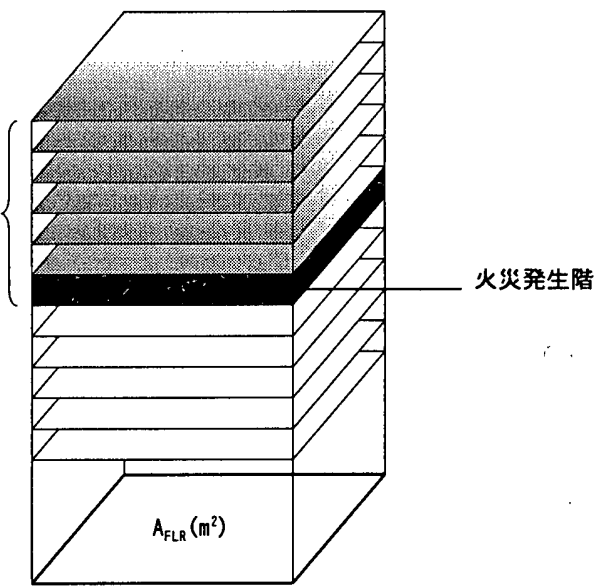

図3·火災リスクの想定条件

任意の 2 つ建築物について高さや規模に拘わらず火災による崩 買に伴う許容火災リスクが同等であるべきと考えると, 式(14)〜 (16)より

$R_{a}=\delta \bar{P}_{F} \bar{A}_{F L R} \bar{P}_{F O} \bar{P}_{S U P} \bar{p}_{f a i l} \bar{N} \bar{A}_{F L R} \bar{Y}_{L} \bar{I}$

$=\delta P_{F} A_{F L R} P_{F O} P_{S U P} p_{\text {fail }} N A_{F L R} Y_{L} I$

と表現できる。ここで $\mathrm{R}_{\mathrm{a}}$ は任意の建築物の許容火災リスク(-)であ

る。上式の一が付いた変数は基準条件に対応するものと考え，この ときの崩壊確率- も予め知られているものと仮定すると, 一般の場 合の許容される崩壊確率が条件に応じて次式のように定められる。

$p_{\text {fail }}=\left(\frac{\bar{P}_{F}}{P_{F}}\right)\left(\frac{\bar{P}_{F O}}{P_{F O}}\right)\left(\frac{\bar{P}_{S U P}}{P_{S U P}}\right)\left(\frac{\bar{N}}{N}\right)\left(\frac{\bar{A}_{F L R}}{A_{F L R}}\right)^{2}\left(\frac{\bar{Y}}{Y}\right)\left(\frac{\bar{I}}{I}\right) \bar{p}_{f a i l}$

ただし，上式中の各括弧内の確率値については絶対值を知る必要 は必ずしもなく，基準条件に対する相対值で良い。

\section{3. 設計可燃物密度の算出}

本稿では, 崩壊確率 $\mathrm{p}_{\mathrm{fail}}$ は

a)火災継続時間は可燃物密度とともに確率分布する。

b)建築物の各部材の耐火時間は確率分布せず一定とする。

c)火災継続時間が耐火時間を超過するとき崩壊する。

という仮定に従うものとする。

これら仮定に従えば, 任意の用途について可然物密度の平均值 $\mu_{w}$, および標準偏差 $\sigma_{w}$ が与えられたとき，式(9)および(10)より，火災 継続時間の対数正規分布の平均值 $\mu_{l n t}$ および標準偏差 $\sigma_{l n t}$ が確定す る。従って, 建築物の構造に備わる耐火時間が $t_{X}$ のとき,

$\tau_{X} \equiv \frac{\ln t_{X}-\mu_{\ln t}}{\sigma_{\ln t}}$

とすれば, 崩壊確率 $p_{\text {fail }}\left(t_{x}\right)$ は, 火災継続時間が而火時間を超過する 確率であり,

$p_{\text {fail }}\left(t_{X}\right)=\frac{1}{\sqrt{2 \pi}} \int_{\tau_{X}}^{\infty} \exp \left(-\frac{\tau^{2}}{2}\right) d \tau \equiv \Phi\left(\tau_{X}\right)$

で計算できる。

逆に崩壊確率に対応する設計可燃物密度は, 次のようにして算出 する。すなわち上式から基準化火災継続時間 $\tau \mathrm{x}$ を

$\tau_{X}=\Phi^{-1}\left(p_{\text {fail }}\right)$

として求めることが出来れば，実火災継続時間は

$\ln t_{X}=\mu_{\ln t}+\tau_{x} \sigma_{\ln t}$

従って,

$t_{X}=\frac{\mu_{x} S}{\sqrt{1+\left(\frac{\sigma_{x}}{\mu_{x}}\right)^{2}}} \exp \left[\tau_{x} \sqrt{\ln \left\{1+\left(\frac{\sigma_{x}}{\mu_{x}}\right)^{2}\right\}}\right.$.

となる。上式から火災継続時間は $S$ ，すなわち空間床面積 $\mathrm{AFLR}_{\mathrm{FLR}}$ およ び開口因子 $\mathrm{AH}^{1 / 2}$ に依存する值となるが，この実火災継続時間から 設計可燃物密度 wx

$w_{X}=\frac{t_{X}}{S}=\frac{\mu_{x}}{\sqrt{1+\left(\frac{\sigma_{x}}{\mu_{x}}\right)^{2}}} \exp \left[\tau_{x} \sqrt{\ln \left\{1+\left(\frac{\sigma_{x}}{\mu_{x}}\right)^{2}\right\}}\right]$

となり，火災空間の条件によらず可燃物密度の平均值および標準偏 差からのみ定まる。この可然物密度の条件の下に火災に耐える性能 を持つ建築構造部材は崩壊確率が許容值以下ということになる。

\section{4.”許容火災リスクから求めた崩壊確率}

\section{1 設計火災の設定}

以上で崩壊確率 pfail から可燃物密度の具体的な設定手法を示した。 しかし，式(18)で分かるように許容される崩壊確率 p fail を計算する ためには基準となる建築物条件とその時の崩塄確率を予め設定する 必要がある。基準となる建築物の選定では, 仕様基準で示される 1 時間， 2 時間などの耐火時間が明示されている建築物を選ぶのが自 然であろう。一方，基準となる建築物の条件が特定されたとしても 区画火災性状は，温度因子や周壁熱特性に依存して多様である。そ こで，仕様基準の耐火性能を示す基淮がどのような火災を想定して 
いるか明らかにする必要がある。これに関し建築基準法では JS1304で与えられる標準加熱曲線による耐火試験が参照されてき た。そこで法規が規定している火災の生ずる条件を以下に検討する。 まず区画火災の温度予測は次式により可能であることが知られてい る 7)8)

$\frac{\Delta T_{F}}{T_{\infty}}=3.0\left(\frac{A \sqrt{H}}{A_{T}}\right)^{1 / 3}\left(\frac{t}{k \rho c}\right)^{1 / 6}$

ここで壁, 床などの区画材料として最も一般的な普通コンクリート の区画壁で考えれば

$\frac{t}{k \rho c} \approx 0.3 t$

程度である。JS1304 の標準加熱曲線は $1 \mathrm{~h}=3,600 \mathrm{sec}$ で $925^{\circ} \mathrm{C}$ ，す なわち概ね

$\frac{\Delta T_{F}}{T_{\infty}} \approx 3.0$

であることを考慮すれば, ЛS1304 の加熱条件は

$\frac{A \sqrt{H}}{A_{T}}=\left(\frac{\Delta T_{F} / T_{\infty}}{3.0}\right)^{3} \frac{1}{(0.3 t)^{1 / 2}} \approx \frac{1}{33} \approx 0.03$

のような温度因子を持つ区画の火災に於いて発生することになる。 因みに式(28)の温度因子の值は実際の建築空間の条件においては非 現実的な値ではない。

上記の值を用いると式(5)の S の値は

$S=\frac{A_{F L R}}{0.1 A \sqrt{H}}=10\left(\frac{A_{T}}{A \sqrt{H}}\right)\left(\frac{A_{F L R}}{A_{T}}\right) \approx 330\left(\frac{A_{F L R}}{A_{T}}\right)$

となる。ここで発生するパラメーター $\mathrm{A}_{\mathrm{FLR}} / \mathrm{A}_{\mathrm{T}}$ は区画の総内壁表面 積に対する床面積の割合であるが，通常の天井高さのオフィス空間 について床面積 $100 \mathrm{~m}^{2} \sim 1,500 \mathrm{~m}^{2}$ の範囲で概算すると

$0.3 \leq \frac{A_{F L R}}{A_{T}} \leq 0.42$

程度である。そこで，中間值 0.36 をとり $\mathrm{S}$ を求めると

$S=330 \times 0.36=119$

となる。従って，標準条件に対して式(8)の $\mu$ Int を計算するために必 要な S が評価できたことになる。

\section{2 崩壊確率の算定}

1）仕様基準の耐火時間之崩壊確率

既往の可燃物調查によれば，事務所用途の居室の可燃物密度の平 均値と標準偏差は, 事務系で $\mu_{\mathrm{w}}=24.3, \sigma_{\mathrm{w}}=6.8$, 技術系で $\mu_{\mathrm{w}}=46.7$, $\sigma_{\mathrm{w}}=10.5$ であった ${ }^{3)}$ 。可然物密度がこの $\mu_{\mathrm{w}}$ と $\sigma_{\mathrm{w}}$ で対数正規分布す るとして, 仕様基準で 1 時間から 3 時間の耐火時間を要求される構 造部材が崩壊する確率を計算する。なお，ここでは $\mathrm{S}=119$ とし計算 を行う。表 1 は, この条件での崩壊確率の算定結果を示している。

表 1 崩壊確率算定結果

\begin{tabular}{|c|c|c|}
\hline & $\mu_{\mathrm{w}}=24.3, \sigma_{\mathrm{w}}=6.8$ & $\mu_{\mathrm{w}}=46.7, \sigma_{\mathrm{w}}=10.5$ \\
\hline $\mathrm{p}_{\text {fail }}(1 \mathrm{~h}=3600 \mathrm{sec})$ & 0.17 & 0.97 \\
\hline $\mathrm{p}_{\text {fail }}(2 \mathrm{~h}=7200 \mathrm{sec})$ & $2.7 \times 10^{-4}$ & 0.10 \\
\hline $\mathrm{p}_{\text {fail }}(3 \mathrm{~h}=10800 \mathrm{sec})$ & $4 \times 10^{-7}$ & $9.6 \times 10^{-4}$ \\
\hline
\end{tabular}

表 1 の結果が示すとおり，全般的に崩壊確率が高い值を示す傾向 にあり，特に耐火時間が 1 時間(1h)の場合には崩壊確率 0.17 あるい は 0.97 と非常に高い值を示す結果となった。これは実際の火災で建 築物が崩壊することは稀にしか遭遇しないという経験的事実と矛盾 する。この理由としては次のようなものが考えられる。

a)防火仕様基準がある程度の安全率をもって定められている。

b)消防による消火作業のため，可燃物がすべて燃え尽きる以前に鎮 火する場合が多い。

c)盛期火災が続いた場合の崩壊確率は高いとしても，実際に崩壊に よる損失が発生する確率は, 式(14)のように出火率や盛期火災にな る確率が関係するため小さくなっている。

d)構造設計その他において種々の安全率が加わるため, 法規の基準 より耐火性能が高くなっている。

\section{2 ）規定の耐火被覆された実際の柱の崩壊確率}

そこで上記の a)，d）の理由について，以下に仕様基準により定め られた耐火被覆部材の実耐火性能を検証する。図 4 には試験体とし

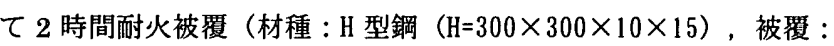
繊維混入珠酸カルシウム板, 厚さ $40 \mathrm{~mm}$ ) の柱で軸力比が異なる場合 の崩壊に至るまでの載荷加熱時間 ${ }^{9)}$, また実際に設計計画された S 造の建築物において，2 時間耐火被覆の柱にかかる軸力比の設計値 を調査集計した結果を示している 10\%。

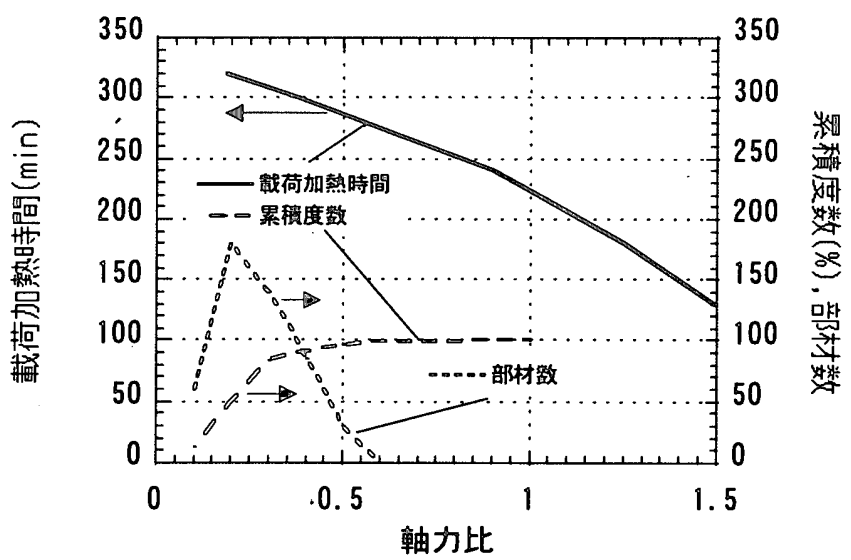
図4 鉄骨中の軸力比と降伏までの載荷加熱時間の関係
および軸力比に対する部材数と累皘度数

この結果からも, 試験体の軸力比が小さいほど崩壊に至るまでの 載荷加熱時間の延びる，すなわち同じ 2 時間耐火被覆の柱であって も，その柱に加わる軸力により崩壊確率は異なることが分かる。ま た実際の $\mathrm{S}$ 造建築物の調查からは 2 時間耐火被覆の柱に対し, 軸力 比は 0.2 程度で設計されている頻度が最も高く, 軸力比が 0.4 まで の累積度数は $95 \%$ 以上となる。

図 4 から軸力比に対する崩壊に至るまでの載荷加熱時間を崩壊時 間とし読みとり, 可燃物密度を $\mu_{\mathrm{w}}=24.3, \sigma_{\mathrm{w}}=6.8$, および $\mu_{\mathrm{w}}=46.7$, $\sigma_{\mathrm{w}}=10.5$ とした場合の各軸力比に対する崩壊確率 $\mathrm{p}_{\text {fail }}$ を式(19), (20) を用いて計算した結果を表 2 に示す。 
表2 軸力比と崩壊確率 $\mathrm{p}_{\text {fail }}$ の関係

\begin{tabular}{|c|c|c|c|}
\hline 軸力比 & 崩壊時間 $(\mathrm{min})$ & $\begin{array}{c}\mathrm{p}_{\text {fail }} \\
\mu_{\mathrm{w}}=24.3 \\
\sigma_{\mathrm{w}}=6.8\end{array}$ & $\begin{array}{c}\mathrm{p}_{\text {fail }} \\
\mu_{\mathrm{w}}=46.7 \\
\sigma_{\mathrm{w}}=10.5\end{array}$ \\
\hline 0.2 & 320 & $1.02 \times 10^{-12}$ & $6.23 \times 10^{-9}$ \\
\hline 0.4 & 290 & $1.26 \times 10^{-11}$ & $7.60 \times 10^{-8}$ \\
\hline 0.6 & 270 & $7.17 \times 10^{-11}$ & $4.14 \times 10^{-7}$ \\
\hline 0.8 & 250 & $4.33 \times 10^{-10}$ & $2.30 \times 10^{-6}$ \\
\hline 1.0 & 220 & $7.28 \times 10^{-9}$ & $3.08 \times 10^{-5}$ \\
\hline \multicolumn{3}{|r}{} \\
\hline
\end{tabular}

表 2 より分かるとおり，仕様基準が持つ安全率と実際の設計で加 わる余裕のために，実際には建物構造の崩壊確率は大幅に小さくな ることが推定される。

\section{3 階数ごとの朤壊確率}

次に基準条件での崩壊確率 $\mathrm{p}_{\mathrm{fa} \text { i } 1}$ を仕様基準とほぼ同等になるよう に定めることを考える。仕様基準では，1，2，3 時間の 3 段階の規 定があるが，ここでは基準条件として 2 時間の耐火性能をとる。こ の対象となる建築物の階数は, 最上階から数え 5 層から 14 層まで であることを考慮し， $\bar{N}=5$ 階, 10 階, 14 階とした場合について 計算する。

式(18)から階床面積その他の条件をすべて同一として, 建物階数 のみを変動数とした場合の許容崩壊確率 $\bar{p}_{\text {fail }}$ は単に

$p_{\text {fail }}=\frac{\bar{N}}{N} \bar{p}_{\text {fail }}$

となる。この $\bar{p}_{\text {faii }}$ に表 1 の $\bar{p}_{\text {fail }}(2 h)$ の值を用いて計算した結果が図 5 である。それぞれのケースについて太い実線は，仕様基準に基づい た許容崩壊確率， 3 本の曲線はそれぞれ基準の階数 $\bar{N}$ を $5,10,14$ とした場合の許容崩壊確率である。

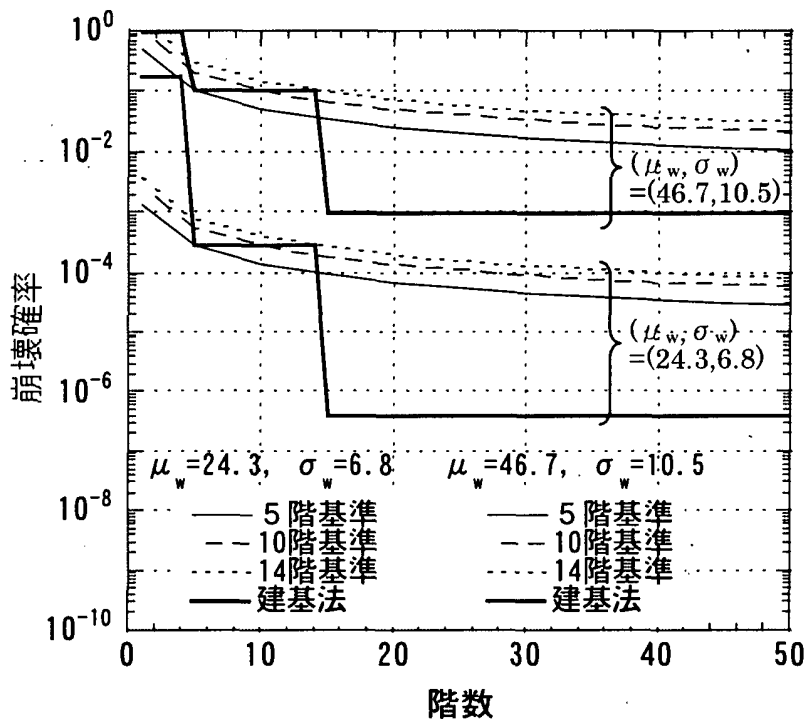

図5 許容崩壊確率と火災階より上方の階数の相関

図 5 では，許容崩罗確率は仕様基準に基づいた值と式(32)で算定 された値では階数の大のところと小のところで差異が大きくなって いる。しかし，これは階数のみを変数として，その他を同一として いるためである。一般には階数が大きいほど，床面積も増大するこ
とが考えられ，また使用年数や重要度も大きくなる可能性がある。 これらを反映させれば差は縮むものと考えられる。

\section{5. 崩壊確率の基準式の設定}

ここで式(18)を用い建築物の崩壊確率を計算するための基準式を 設定する。ただし，仕様基準が 2 時間耐火性能を想定している条件 として表 3 の值を仮定し，これを建築物の諸条件とする。これに関 しては異論もあると考えられるが, 論理的に追求することはできず, 多分に社会常識に基づいた判断に依存するしかない問題である。

表3 基準条件

\begin{tabular}{|c|c|}
\hline 階数 & 10 階 \\
\hline 床面積 & $1500 \mathrm{~m}^{2}$ \\
\hline 耐用年数 & 50 年 \\
\hline 可燃物密度 平均值 & $24.3 \mathrm{~kg} / \mathrm{m}^{2}$ \\
& $6.8 \mathrm{~kg} / \mathrm{m}^{2}$ \\
\hline 偏差 & $2.7 \times 10^{-4}$ \\
\hline 崩壊確率 & \\
\hline
\end{tabular}

表 3 に示した基準条件を用い，式(18)を整理すると

$p_{\text {fail }}=2.7 \times 10^{4}\left(\frac{\bar{P}_{F}}{P_{F}}\right)\left(\frac{\bar{P}_{F O}}{P_{F O}}\right)\left(\frac{\bar{P}_{S U P}}{P_{S U P}}\right)\left(\frac{\bar{I}}{I}\right)\left(\frac{10}{N}\right)\left(\frac{1500}{A_{F L R}}\right)^{2}\left(\frac{50}{Y}\right)$

となる。さらに式(33)中の建築物の出火確率, フラッシュオーバー の発生確率, 消防による火災鎮圧率, および建築物の重要度の数值 の設定を行えば崩壊確率を算定することが可能となる。以下にそれ ら数值の一例を示す。

まず, 建築物の出火確率は, 建築物の主用途の中から, 事務所, 物販，住宅について整理を行った 11) 14)。その結果，用途別に出火 率を求めると以下の通りとなる。

表4 用途別出火率

\begin{tabular}{|c|c|}
\hline 用途 & 出火率(件 $/ \mathrm{m}^{2}$ 年) \\
\hline 事務所 & $6.67 \times 10^{-7}$ \\
\hline 物販 & $4.12 \times 10^{-6}$ \\
\hline 住宅 & $6.43 \times 10^{-6}$ \\
\hline
\end{tabular}

表 4 の值から事務所の出火率を基準值とし，物販および住宅の出 火率を相対值で表すと概ね次の值が得られる。

$\left(\frac{\bar{P}_{F}}{P_{F}}\right)=\left\{\begin{array}{cl}1 & \text { 事務所 } \\ 1 / 6 & \text { 物販 } \\ 1 / 10 & \text { 住宅 }\end{array}\right.$

ついでフラッシュオーバーの発生確率は，スプリンクラーの設置 の有無をもとに設定を行う。仕様基準ではスプリンクラ一の設置に より，面積区画が 2 倍の広さまで緩和されることを踏まえ以下の通 り設定できる。

$\left(\frac{\bar{P}_{F O}}{P_{F O}}\right)= \begin{cases}1 & \text { スプリンクラー } \\ 4 & \text { スプリンクラー }\end{cases}$

ちなみに, カナダ, 米国の調査ではスプリンクラーが設置された 場合, フラッシュオーバーの確率は $1 / 4$ から $1 / 5$ となるという研究 結果 15)もあり，この設定は統計的には概ね妥当と考えられる。 
消防活動による火炎鎮圧確率については，建築物の構造種ごとに 分別し火災一件当たりの焼損面積から求めることとした。表 5 は建 物構造別の火災一件当たりの焼損面積を示している ${ }^{16) 。}$

表5 火元構造別損害状況

\begin{tabular}{|c|c|}
\hline 建物構造 & $\begin{array}{c}\text { 一件当たりの焼損面積 } \\
\left(\mathrm{m}^{2} / \text { 件 }\right)\end{array}$ \\
\hline 耐火造 & 10.4 \\
\hline 防火造 & 30.5 \\
\hline 木造 & 66.2 \\
\hline
\end{tabular}

この表 5 の値に基づき火災鎮圧確率を下記の通り定めた。

$$
\left(\frac{\bar{P}_{\text {SUP }}}{P_{\text {SUP }}}\right)= \begin{cases}1 & \text { 耐火造 } \\ 1 / 3 & \text { 防火造 } \\ 1 / 7 & \text { 木造 }\end{cases}
$$

建築物の重要度は, 地域性や社会性など様々な状況下で決定され る值であるが,ここでは以下の通りとする。

$\left(\frac{\bar{I}}{I}\right)=1$

\section{6. ケーススタディ}

式(33)より求められる崩壊確率 p fail から式(21), (24)より計算され る設計可燃物密度の傾向を把握するため，事務所用途を対象とした ケーススタティをここで行う。ケーススタディでは, 表 6 に示した 通り，事務所用途を事務系と技術系に分け，階数之階床面積を変化 させる計算条件を設定した。

表6 計算条件

\begin{tabular}{|c|c|c|c|}
\hline \multirow{2}{*}{\multicolumn{2}{|c|}{ 用途 }} & \multicolumn{2}{|c|}{ 事務所 } \\
\hline & & 事務系 & 技術系 \\
\hline \multicolumn{2}{|c|}{ 火災階から上方の階数(N) } & \multicolumn{2}{|c|}{$1 \sim 50$} \\
\hline \multicolumn{2}{|c|}{ 階床面積 $\left(\mathrm{AFLR}_{\mathrm{FLR}}\right)$} & \multicolumn{2}{|c|}{$500,1500,2500,3500$} \\
\hline \multicolumn{2}{|c|}{ 耐用年数 } & \multicolumn{2}{|c|}{50} \\
\hline \multirow{2}{*}{$\begin{array}{l}\text { 可然物 } \\
\text { 密度 }\end{array}$} & 平均 & 24.6 & 46.7 \\
\hline & 偏差 & 6.8 & 10.5 \\
\hline \multicolumn{2}{|c|}{ スプリンクラー $\left(\mathrm{P}_{\mathrm{FO}}\right)$} & \multicolumn{2}{|c|}{$\begin{array}{l}\text { 有, 無 } \\
\end{array}$} \\
\hline \multicolumn{2}{|c|}{ 構造 } & \multicolumn{2}{|c|}{ 耐火造 } \\
\hline
\end{tabular}

まず式(33)を表 6 の計算条件をもとに, 火災階から上方の階数 N, および階床面積 AFLR を変数とし整理すると

$p_{\text {fail }}=\frac{\kappa}{N \times A_{F L R}^{2}}$

$\kappa= \begin{cases}1.38 \times 10^{5} & \text { スプリンクラー 無 } \\ 5.51 \times 10^{s} & \text { スプリンクラー }\end{cases}$

となる。式(38)から設計可燃物密度を計算した結果をそれぞれ事務 系と技術系に分け図 $6 \mathrm{a}$ )b)に示す。また図 6 には，表 6 で与えられ た可然物密度の平均と偏差から求めた確率密度分布も併記している。

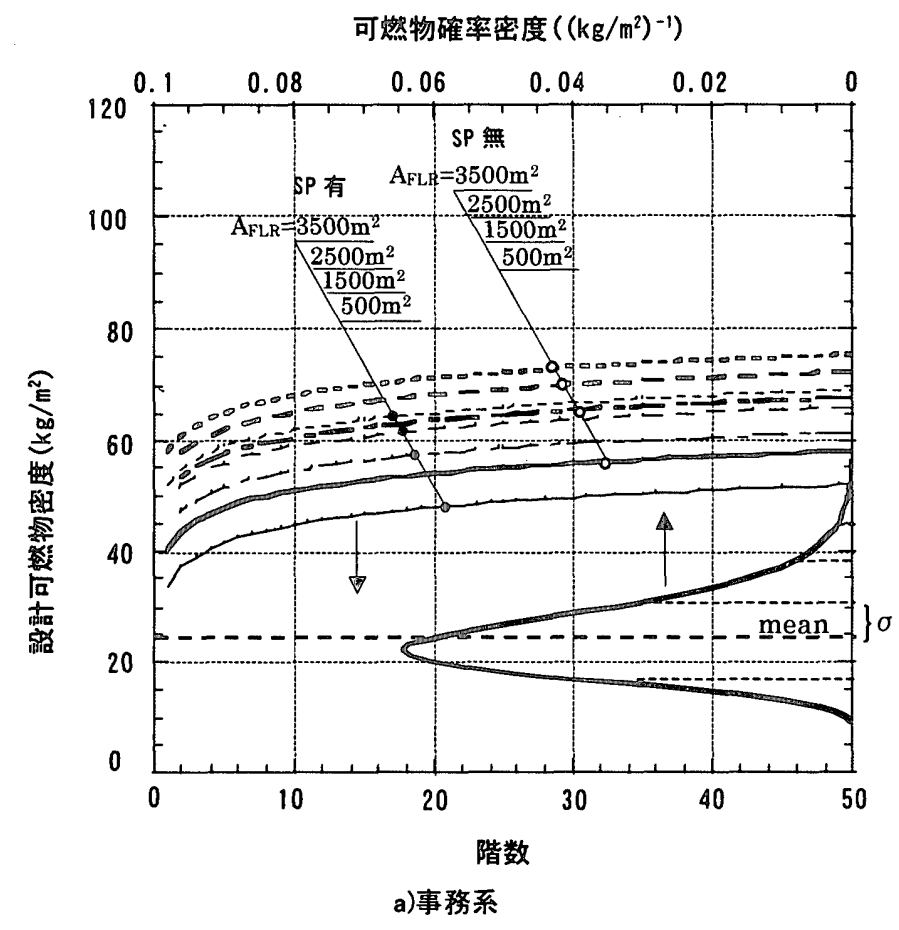

可燃物磪密密度 $\left(\left(\mathrm{kg} / \mathrm{m}^{2}\right)^{-1}\right)$

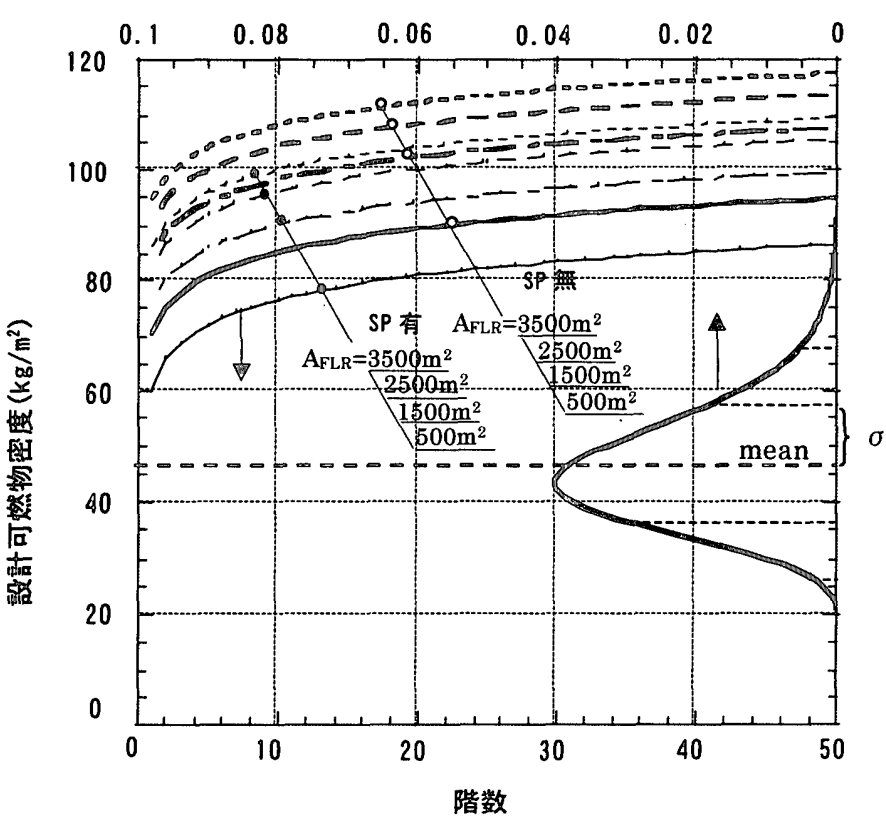

b)技街系

图6 設計可燃物密度

図 6 より, 階床面積が大きい值をとる程, 任意の階数における可 然物密度の絶対値は大きくなる。そして, 階床面積を同一条件とし スプリンクラーの設置の有無による任意の階数における可燃物密度 の絶対值を比較すると，スプリンクラーの設置により可然物密度の 絶対值は減少し，さらに各階数ごとにスプリンクラーの設置しない 条件から設置する条件での可燃物密度を差し引いた值は, 階数にか かわらず概ね等しくなる傾向にある。また，事務系と技術系の可燃 物密度の絶対値を比較した場合, 事務系に比べ技術系の方が全体的 に高い值を示し, さらに階床面積の違いによる可然物密度の差も大 
きくなる傾向にあり，これらは可燃物密度の平均および偏差が技術 系の方が大きいことに起因する。

さらに図 6 の結果をもとに, 階数 $\mathrm{N}$ が 1 となる条件での可燃物密

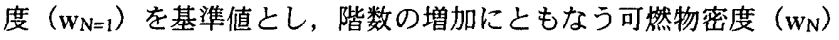
の変化量の相対比（ $\mathrm{w}_{\mathrm{N}} / \mathrm{w}_{\mathrm{N}=1}$ ），および任意の階数ごとにスプリン クラーを設置しない条件での可燃物密度（ $\mathrm{w}_{\mathrm{N}, \mathrm{SP}}$ 無）を基準値とし, 階床面積を同一としたスプリンクラーを設置する条件での可燃物密

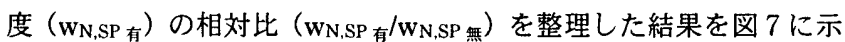
す。

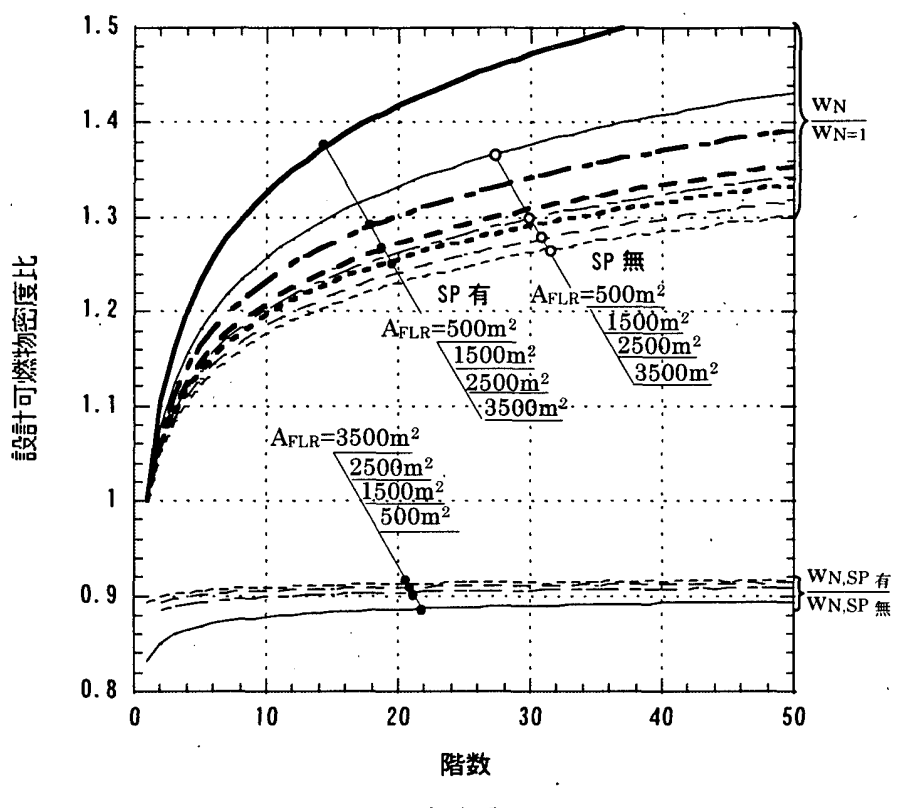

a)事務系

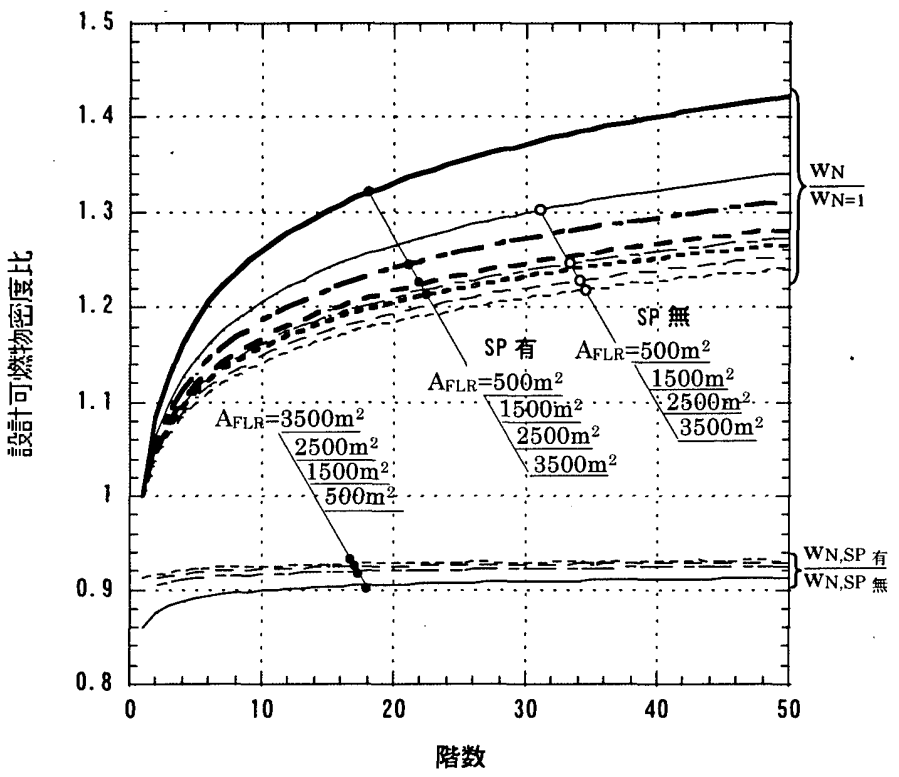

b)技術系

図7 可然物密度比

図 7 より，階数 1 を基準値とした相対比 $\mathrm{w}_{\mathrm{N}} / \mathrm{w}_{\mathrm{N}=1}$ の值に着目する と, 階床面積が小さいほど, 階数の增加に対し相対比の值は大きく
なる傾向にある。また，階床面積が同一の条件でスプリンクラーの 設置の有無による差に着目すれば， スプリンクラーを設置した条件 は，設置しない条件より任意の階数における相対比は大きくなる傾 向にある。

つづいて，スプリンクラーの設置の有無による可燃物密度の相対 比（ $\mathbf{w}_{\mathrm{N}, \mathrm{SP}}$ 有 $/ \mathrm{w}_{\mathrm{N}, \mathrm{SP}}$ 無）に着目すると，階数が増加するに従い，相対比 は大きくなるが, 本計算条件で設定した階数の範囲では，相対比が 概ね 0.9 前後の値をとることが分かる。すなわち，スプリンクラー の設置により, 設計可燃物密度は 1 割程度低減されることになる。

これらケーススタディの結果を踏まえ，注意すべき点は，

a)許容崩壊確率が等しい場合でも，可燃物密度の小さい方が設計可 燃物密度の絶対值は小さくなる。

b)可燃物密度分布が等しい場合でも，開口因子，温度因子等空間の 条件により火災性状が異なるので要求耐火性能は一律とならない。 ということである。これらが建築物の条件に応じた耐火設計の合理 性と柔軟性をもたらす因子となる。

\section{7. まとめ}

本稿では, リスク概念を用い建築物の許容火災リスクを建築物の 高さや規模等によらず同一であるべきことを前提とし構造部材の許 容崩壊確率を求め，それに対応する設計可燃物密度の算出方法を提 案することを試みた。本稿による成果をまとめると以下の通りとな る。

a)建築物に持ち込まれる可燃物密度の確率分布から，火災継続時間 分布を算出する方法を誘導した。

b)建築物の許容崩壊確率について, 建築物の火災リスクに基づき算 定方法を提示し，崩壊確率を算定するための基準式を示した。 c)仕様基準で要求される耐火性能をもつ構造の崩壊確率を計算した 結果，その值は全般的に高い値を示した。そこで仕様基準による 2 時間耐火被覆部材の実耐火性能を求め, 仕様基準の安全率の程度を 確認した。 d)建築物の設計可然物密度についてケーススタティを行い，その計 算結果を示すとともにその傾向を把握した。

今後は, 許容される崩壊確率の基準式を構成する種々のパラメー 夕值の充実や，区画構成部材の延焼防止性能などについても本稿の 考え方を適用し明らかにしていく。

\section{凡例}

$\mathrm{A}$ :開口面積 $\left(\mathrm{m}^{2}\right)$

$\mathrm{A}_{\mathrm{FLR}}:$ 床面積 $\left(\mathrm{m}^{2}\right)$

$\mathrm{A}_{\mathrm{T}}$ : 周壁面積 $\left(\mathrm{m}^{2}\right)$

$\mathrm{c}:$ 比熱 $(\mathrm{kJ} / \mathrm{kgK})$

$\mathrm{H}$ : 開口高さ (m)

$\mathrm{k}$ : 熱伝導率 $(\mathrm{kW} / \mathrm{mK})$

$\mathrm{m}_{\mathrm{b}}:$ 重量減少速度 $(\mathrm{kg} / \mathrm{s})$

$\mathrm{N}$ : 火災階より上方の階数 (階)

$\mathrm{P}_{\mathrm{F}}$ : 単位床面積当たり単位期間当たりの火災発生確率 $\left(1 / \mathrm{m}^{2}\right.$ 年)

$\mathrm{P}_{[\mathrm{a} i \mathrm{i}}$ : 崩塄確率 (-)

$\mathrm{P}_{\mathrm{Fire}}$ : 火災発生確率 $(-)$

$\mathrm{P}_{\mathrm{F} 0}$ :出火した火災が火盛り期に成長する確率(-) 


\section{$\mathrm{P}_{\mathrm{L}}:$ 火災損害発生確率 $(-)$}

$\mathrm{P}_{\mathrm{Sup}}:$ 消防が火災鎮圧に失敗する確率 $(-)$

$\mathrm{R}:$ 火災リスク (-)

$\mathrm{S}_{\mathrm{L}}$ : 火災損害の潜在的大きさ $(-)$

$\mathrm{t}$ : 火炎継続時間 $(\mathrm{sec})$

$\triangle T_{F}$ : 上昇温度 $(K)$

$\mathrm{T}_{\infty}$ :雾囲気温度 $(\mathrm{K})$

$\mathrm{w}:$ 可然物密度 $\left(\mathrm{kg} / \mathrm{m}^{2}\right)$

$\mathrm{Y}_{\mathrm{L}}:$ 耐用年数 (年)

$\delta:$ 安全率によるリスク低減係数 (-)

$\rho:$ 密度 $\left(\mathrm{kg} / \mathrm{m}^{3}\right)$

\section{参考文献}

1) Bukoski, R. W.: Fire Safety Engineering in Pursuit of Performance-based Codes: Collected Papers, NISTIR 5878 (CIB Report: CIB W 14/96/5, NIST

2) K. Harada, T. Tanaka, T. Morita : Rational Framework for Fire Resistance Requirement Based on Relative Risk Concept, Fire and Explosion Hazard of Substances and Venting of Deflagrations, Proceedings of the Second International Seminar, pp.365-376, 1997

3）松山蜸：「性能的火災安全設計法に用いる火災性状モテルの構策と火炎 安全性能謤価への応用」, 東京理科大学博士論文, 2000.3

4) Chou, H.: Reliability-based Design of Structure, Sankaido

5）油野健志，山仲秀利，大宮喜文，高橋清，田中哮義，若松孝旺：「実態 調查に基づく可燃物量とその表面楮の分析」，日本建筑学会計画系諭文
集, No.483, pp.1·8, 1996.5

6）市川昌弘：「構造信賴性工学一強㡲設計と寿命予測のための信頼性手法 一」海文堂, 1996.3

7) McCaffery, B.J., Quintiere, J. G. and Harklerload, M. F.: Estimating Room Temperatures and Likelihood of Flashover Using Fire Test Data Correlation, Fire Technology, Vol. 17, No.2, pp98·119, 1981

8）松山賢, 藤田隆史, 金子英樹, 大宮喜文, 田中哮義, 若松孝旺 :「区画 火災性状の簡易予測法」，日本建築学会構造系論文集，No.469， pp.159-164, 1995.3

9）播磨政弘, 遊佐秀冕, 吉田正友, 岡村義徳 :「舒製柱の耐火性能評価（そ の 2 実験結果および考察)」, 日本建築学会大会学術講演梗概集 (関東)， pp155・156, 1997.9

10）斎藤秀人, 大内富夫, 湯谷孝夫, 西垣太郎, 丹羽博則, 宮本圭一, 谷田 貝健, 高橋済:「建築構造物の長期設計荷重時応力 (その 3 柱部材) 」, 日本建築学会大会学術講演梗概集 (関東), pp169-170, 1997.9

11）「火災の実態平成 10 年版」, 東京消防庁予防部予防課, 1998.6

12）「東京の土地 1997 (土地関係資料)」, 東京都政策報道室調查部, 1998.5

13）「東京の土地 1998 (土地関倸資料)」, 東京都政策報道室調查部, 1999.5

14）「東京の小売業 (平成 9 年商業統計報告 小売業態別集計編) 」, 東京都 総務局統計部商工統計課, 1999.9

15) Gaskin, J. and Yung, D.: Canadian and U.S.A. Fire Statistics for Use in the Risk-Cost Assessment Model, Internal Report No. 637, pp4-6, 1993.1

16）「火災便覧 第 3 版」，日本火災学会編，共立出版，1997.5 